\title{
Exploration of tourism potential doing concepts of development and heritage preservation issues of Zonouz city
}

\author{
Hassan Khalili Zonouz, Rahibe Aliyeva, Azerbaijan National Academy of Sciences, \\ Mitra Azad, Shahid Beheshti University, Iran
}

\begin{abstract}
Zonouz city and its neighboring counties, including three counties and eleven areas, are located in the southern area of the Araz River in Azerbaijan and northwest of Iran. This city has many capabilities in terms of geography, civilization, and tourism, which can be considered as an advantage in urban development.

The development in the city is a process occurs by relying on introversion and utilizing extraversion, among which urban regeneration can be highlighted. Thus, recognizing the components of empowerment is one of the main purposes. Applying the rules and observing the necessary principles reduce costs and increase productivity in development.

The present study aims to study and compare the advantages of the city, which have more centrality and relative abilities than the peripheral cities, with those cities having the same geographical and cultural characteristics, and the least distance from the city, in an integrated and complementary collection in the tourism industry.

Considering that different multi-city managers should similarly play a role, the appropriate reason for their participation can be balanced development and utilization from common interests. This benefit can be achieved based on the management and exploitation of natural and historical attractions, the results of which are synergy and improved performance and exploitation power from the interests.

To this aim, the tourist abilities and natural and tourist attractions of the complex are identified and studied, and the results of the analysis are analyzed. The conclusion can be made based on using natural geography and cultural heritage advantages to protect historical buildings and textures better, along with a balanced development of a series of neighboring cities.
\end{abstract}

Keywords: Zonouz, tourism development, architectural theories, architectural conservation, central district

\section{Introduction}

Historical cities that possess architectural and urbanization works, have been created due to the presence of geographical and human conditions, playing urban and extramural roles during their lifetime. Cities are not independent elements. Following interactions as well as give-and-takes with other population points, they can always develop. City potentialities are not merely limited to the possessions within its territory, it rather depends on meeting other points' demands and its influence is more on the possessions within the city. This feature depends on urban management, professional and efficient human force, service centers, ad geographical area, also being influenced by metropolitan management.

Zonouz is a city in East Azerbaijan Province with a millennia-old history [16]. Meanwhile, the city possesses much natural wealth with its historical landmarks being quite considerable and abundant. Its historical tissue, historical villages, and cultural landscape, which independently are candidates of being registered in UNESCO's world list, allow the city to turn into a powerful tourism center [14]. However, something that has not received any attention so far and every now and again has damaged its set of geographical and artificial possessions. While we can expect that the existing potentials of the city are capable of its growth and development and through necessary interaction with its surrounding cities helps their simultaneous development, too.

The present study tries to find out that in which conditions can rely on its geographical richness as well as surrounding settlements and - along with architectural and urbanization works - make tourism the axis of its development. Can geographical abilities in terms of tourism supply the beginning goals of the city's economy and by means of that restoration of the damages inflicted on historical tissue so that the main economic axis of the city is based on tourism income? And do surrounding cities possess the necessary position and interest for convergence and formation of a powerful center? In this case, how will be design management as well as the distribution of costs and profits among cities, for which Zonouz plays the role of a hub?

Since Zonouz will play the role of the hub for the surrounding cities, it should have necessary conditions in terms of powerfulness along with tools and instruments, for its possessions should be in a way that surrounding cities' managers will gain the necessary profits from convergence [17]. As a result, identification and analysis of tourism as well as evaluation of Zonouz's potentialities need to be studied so that the assumption of playing the role of the tourism metropolis, which is in the present research structure, is proven. Afterwards, motivating 
and giving trust to the managers of cities that participate in the design is another step of the present study, since the independence of surrounding cities' management along with their motivation to take part in the design, by itself, needs analysis and evaluation of utilizing the results of participation by surrounding city's managers. This requires studies on convergence and convergence-based synergy. It also needs making sure about economic interests as well as maintenance of architectural works, located in that area and will supply the necessary infrastructures such as communicative axes. The final section of the study will concern an analysis of the study's findings and results and will state their advantages and disadvantages along with the implementation methodology.

\section{Research Methodology}

There was necessary to collect data via survey of city and geographical potentials since there is impossible to collect data by library study in several seasons. In order to answer the research's main question, i.e. utilization of tourism development in maintenance of cultural heritage of Zonouz and its surrounding cities, and answer secondary questions, it is needed to conduct library-based studies and field data-collection in order to make the necessary identification and, through data analysis, reasoning, and deduction gain the expected results, in which a comparative method can also be useful for further enrichment.

As this is first study about Zonouz city in tourism purposes, all information presented about the city are collected by authors directly from Surveying in different parts of city.

\section{Tourism potentials of area}

According to development planners and policy makers, tourism industry is the main pillar of sustainable development. Due to its extensive use, the term "sustainable development" has been described in various approaches [3]. In general, development is the transformational process of relations between governments, on one hand, and social, economic, and natural systems, on the other [5].

Given the importance of tourism industry, not only the social, cultural, and political factors, but natural and environmental factors play an important role, developing tourism industry and tourist attraction. In fact, tourists use a geographic space with a physical and natural structure, including the biological factors such as climate, geology, topography, and flora and fauna, as well as factors, created by human activities including construction and pilgrimage facilities. The arrival of tourists to any area leads to the creation of a series of jobs at the macro-level, causing social and cultural development.

In today's world, tourism industry has gained many countries' attention as a clean industry which is the third dynamic, thriving, and developing economic phenomenon after oil and automotive industries [3].

Tourism is an industry, the development of which requires enough awareness and knowledge of the effective economic, social, and cultural factors. Without knowing about available facilities in each area, it would not be possible to make plans and predictions, scientifically. Indeed, knowing the social, economic, and natural potentials of each area enables the policy makers to identify its development and direction, based on the current situation and capacities of the region [19].

Considering the practical nature of tourism industry, and in spite of technological improvements in the world, this industry is still based on the significant role of manpower, which becomes still more important in countries with high rates of unemployment that possess the requirements (such as social, historical, and natural resources) to develop its tourism industry. Therefore, we can consider tourism industry a solution to deal with unemployment crisis and in turn reduce inequality and challenge poverty. By improving the local economy, increasing job opportunities, improving investment policies, developing proper infrastructures, increasing tax income, etc., tourism industry can have a huge influence on economic development [7].

Sustainability and development of tourism requires a proper system of education in each country. Using the significant role of human resources for the purpose of tourism industry development, which results from appropriate education, national and local economy of each country can grow rapidly through raising skill and knowledge levels of the local residents. Management training and appropriate use of the environment are some factors to gain sustainable development. Additionally, it will be quite useful to develop a management major in universities in order to scientifically reinforce this industry and motivate the private sector through establishment of colleges and professional institutes, offering tourism and hospitality courses for the sake of developing human resources in this sector [15].

The addition of sustainable features to city tourism is due to the extensive side effects of the tourism development plans in the cities. This issue is efficient only when the four directions of the development, i.e. cultural, environmental, social, and economic development, are defined in national and international levels and in mutual relations between cities and citizens. Alongside social and economic effects of this industry on cities and citizens, what is crucial for sustainable tourism development is the importance of continuing tourism programs over time (for future generations), not to mention the impacts of its development on the geographical location (for the environment). 
Cities are the symbols of civilization in human environment. They evolve, as time passes, based on their territorial phenomenon in a dynamic yet balanced way. They have historical values and their historical structures are regarded as a valuable heritage, alongside their modern structures. Because of the nostalgic, architectural, and cultural attractions as well as historical values which are the symbols of social, religious, and economic conditions of that time, historical structures are among important tourist destinations.

Through presentation of tourist attractions, tourism industry attempts to introduce natural landscapes, while maintaining the local identification. Considering the mutual relation between tourism development and reconstruction of historical structures, utilization of cultural and historical heritage includes many economic, social, and cultural interests for the countries involved. Since the most essential condition of development in any society is security, peace, and stability, they are the first criterion to attract tourists, their related components [15] including national and social security, healthcare, environmental cleanness, and other tourism standards. The standard tourism services are meant to achieve tourists' well-being and convenience during their stay. Therefore, by designing some accommodation complexes in historical contexts, we can attracts a great number of tourists and by re-identifying historical and architectural patterns and using them in modern architectures, we can obtain a plan to revive our ancestors' culture, saving it from destruction. For this purpose, the paper firstly deals with the main concepts, related to this issue, then, in addition to state the importance of the residential locations in the historical contexts for development of tourism industry, the relation between these places and tourism development is studied.

In terms of regional construction, making tourist poles in regions with sufficient resources and attraction significantly helps developing tourism industry there. Accordingly, by creating new jobs and adding resources, we can make income and enrich regions that have high tourism potential yet are experiencing a recession [4]. This, in turn, will reduce rural-urban migrations. Furthermore, by transferring cities' purchasing power to other regions, tourism industry can balance the economic income. It can also increase the local and regional businesses. Despite abundant natural and tourist attractions and sufficient resources, the places, studied in the present paper, could not be identified as tourism center; mainly due to different kinds of problems, including lack of familiarity with tourism industry, inappropriate residential places, problems related to access paths, insufficient investment to develop and equip tourismrelated facilities and implement worthwhile tourism projects, and lack of appropriate advertisements. Identification and introduction of tourism attractions in this region are primary steps to develop ecotourism and, consequently, achieve sustainable development.

The presence of 26 perfect natural tourist attractions and natural history monuments (Fig 1); dozens of rare species of plants; a variety of animal species, some of them quite rare; suitable climatic conditions; worthwhile geographical situations, and developed culture of Zonouz City makes it a perfect tourist resort, all of which have been placed together. From the historical stepped village of Zonuzaq (Fig. 2) to civil context of the Zonouz and Mahar phenomenon, all are capable of attracting domestic and foreign tourists (Fig. 3). In this regard, historical context and monuments and various archaeological sites possess considerable capacity that needs planning.

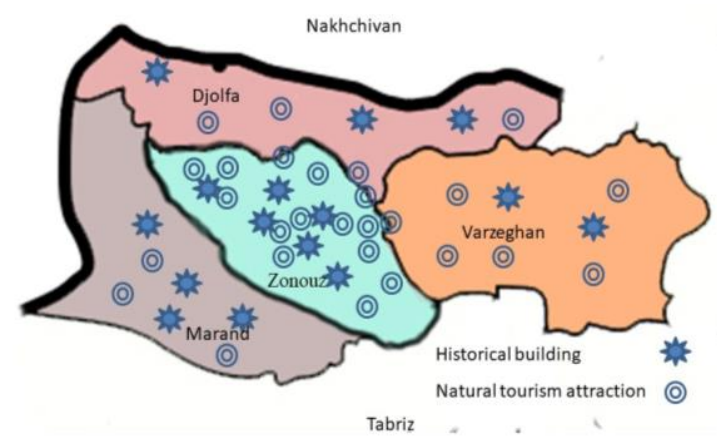

Fig. 1. The Phenomenon's in research area Created by the authors, 2018.

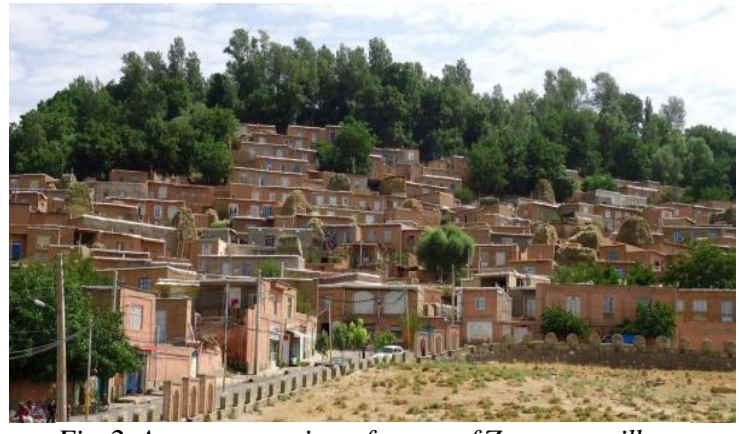

Fig. 2. A panorama view of a part of Zonouzaq village. Photo by Reza Abdorrahimi, 2018.

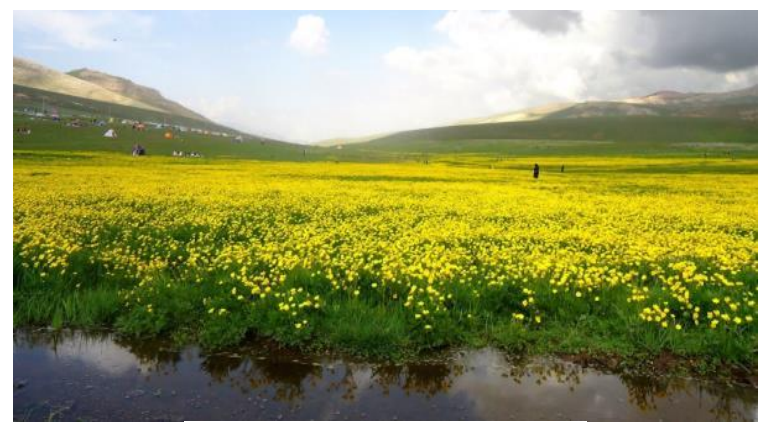

Fig. 3. A panorama view of Mahar Photo by Reza Abdorrahimi, 2018. 


\section{Some tourism aspects of Zonouz City}

In order to present a clear imagination about zonouz city and its ability in playing a role on development of tourism purposes and be come on hub on adjacent cities have to list some potentials.

Although some sections of the Garden-city of Zonuoz have been severely damaged, the remaining sections and, in particular, the original one can be used as tourism attraction. The city's avenues contain historical landscape.

There is unique civil landscape and historical context in different neighborhoods, located south of the city.

The city features hundred hectares of stepped gardens that are considered a natural monument at national and international level and can be a proper candidate for being registered on UNESCO World Heritage List (Fig. 4).

Alongside the three archeological sites, belonging to old Bronze Age up to Iron Age, and showing cultural material of Yaniqe Civilization (KouraAraxes culture), this monument incorporates natural, historical, and cultural heritage, gracefully.

Zonouzaq is the largest historical stepped village that can be a candidate for global record in world heritage list of pristine villages such as Daraq, Darndash, KuKamar, Miab, and Horouz, making a unique natural complex in Azerbaijan region to become a reliable pillar in Iranian tourism industry.

Thanks to the mountainous climate and geotourism of Zonouz valley, some mountains of Qara Daq, and the natural rocks, Zonouz has great tourism potential. The most significacnt tourist attractions are Sultan Zencir Mountain and Kiyamky Mountain, both with beautiful valleys.

Natural attractions and phenomena such as Aghdash and Mahar along with fertile hillsides of Sultan Zencir Mountain, called Soyouk bulaq, which is hundreds of hectares vast, attract thousands of tourists during the spring. Although tourists come from near or far cities, there is a lack of expert botanists and zoologists. What is more, it is required to preserve the rare species of plants and animals, such as Nagorno-cock, wild goat, and urinal, which takes long-term planning in the region.

Enrichment of sport-related tourism attractions, e.g. mountaineering, rock climbing, kite surfing, grass skiing, and snow skiing are some of the most important steps to attract tourists. Moreover, Zonouz Chay Dam and Chokhourzami Dam make it possible to do some water sports. Although the tourism role of these dams has been reduced, compared to other trends of economy they still can still be useful to be chosen as a nice region for economic activities.

In addition to the mentioned potentials, there are many tourist attractions, some of them serving as the global brand of this city. Although due to the lack of required management, the tourism value of some

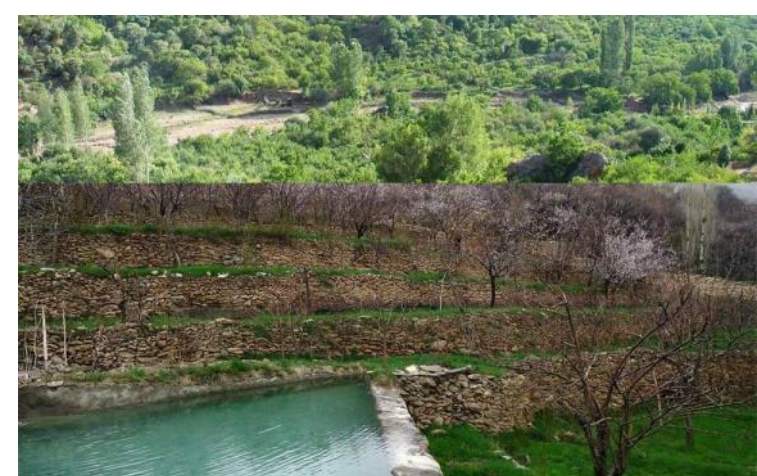

Fig. 4. A panorama view of stepped gardens and their architectural elements. Photo by the authors.

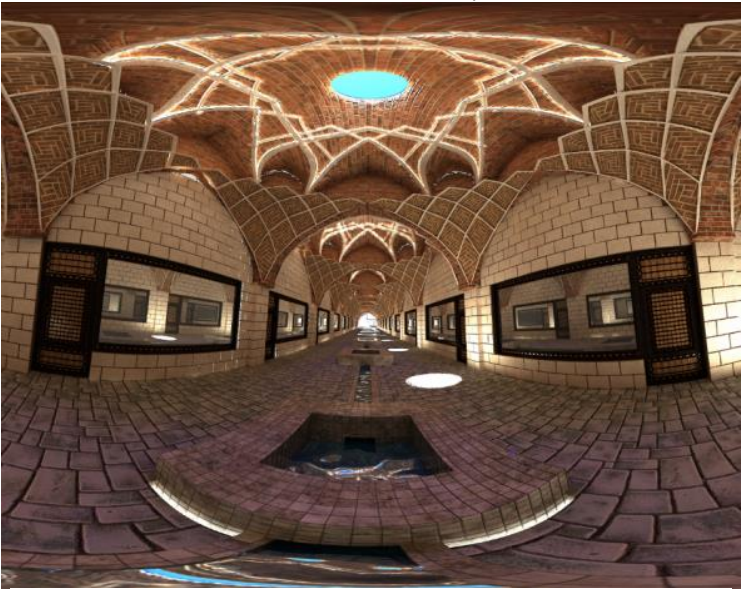

Fig. 5. Reconstruction of Bazar aims at implying the memories and Restoring the city economic status by relying on the economic activities of the market and its historical role in the activities of the city and surrounding cities where Zonouz market was the field ofcommercial activities as traditionally or historically. Skeleton of bazar parameters can be considered as identity of city too. Meantime it is a part of tourism and city development plan. Created by the authors.

tourist attractions such as handicrafts and religious and traditional customs have been reduced, especially in villages and their developed culture has been diminished, they still have the required characteristics to promote tourism industry in this city.

The potentiality of job creation and achievement of economic goals; (Fig.5) hence, the numerous potentialities inside and outside Zonouz city can raise it to the first place in tourism industry. This city also possesses the necessary characteristics to attract foreign tourists. Unfortunately, no proper attention has been paid to this subject, so far. Many tourists have selected this city as the final destination, but some visit it while route on Djolfa-Marand transit route, meaning that despite the almost perfect economic, commercial, and tourism investment in DJolfa city, especially in its ruined Church and Mill, it has not been able to succeed as much as Zonouz tourism industry; therefore, we can conclude that Zonouz plays an important role in economic markets of the region, able to obtain a suitable status in the vicinity of the free zone. 
Ideal distribution of extensive natural attractions encourages the implementation and acceleration of this plan, whose view for the next 20 years can be described below:

Despite the high potentials of tourism industry, not only does Zonouz profit from this industry, but because of the large number of tourists as well as lack of the required facilities, its tourist attractions are being damaged. It can be claimed if this city had not been introduced as a tourism center, it could have been prepared; nonetheless, with regards to its present status we should try to protect its national wealth as quick as possible [11].

Civil projects and plans with physical nature can have both positive and negative effects on civil culture. Previous experience has shown that any physical project is capable of presenting some sort of social function that may be even more obvious than their physical achievements.

For this purpose, by using a number of criteria the appropriate conditions are developed to identify the gap between the present situation and the appropriate one. There are four main methods to determine the latter: In the first, by means of the senior managers' planning the individual standards are provided; while in the second method, the global standards are chosen practically. The third method compares the cities, whereas the final one uses the indicators of the previous years as a suitable criterion for planning and circumstantial changes.

Citizens are pleased with the betterment of tourism; on the other hand, it has caused some concerns among the citizens, which involves the impacts of tourism on the social behavior and interactions of the city. Zonouz has a developed culture and cannot accept the social anomalies, the tourists bring there. Another concern of the citizens' concerns the damage to their orchards and farms. Although the orchards have not been damaged very much, the farms around the city, especially the ones in Aghdash and Mahar, have been destroyed drastically. Moreover, the provided services, offered by the citizens, seeks to obtain more income. Decisionmakers have not been taken this expectation seriously. Finally, in the view of the tourists, necessary facilities have not been implemented in this city.

The concept of development has a broad meaning in different aspects, like economy, society, culture, and policy [5]. Owing to the entanglement of the economic, social, political, and cultural issues in current societies, along with their mutual effects, it seems incorrect to overdevelop one of these aspects more than the others. Then, many of the social and economic theorists believe that economic development has a close relation to other aspects of development [5]. In total, development is a process that includes some changes, performed to flourish and fulfill the latent capacity of the society; however, the concept of development is a subjective concept, for which we cannot present a united definition.

In modern theories of development, it is considered as a concept beyond economic growth, for it is a multi-dimensional process, including different orientations of the economic-social system, totally. In addition to improvement of the product level and income, development includes fundamental changes in the official, social bodies and even people's opinions. In many cases, it includes the customs and beliefs of the people, based on which, all dimensions of human life should be known in order to determine the developmental goals. According to sociologists and political scientists, development is an aspect of reconstruction that establishes the social and political bodies [6]; in other words, it is a transition to a worthwhile situation that might be created in a social system.

By studying the concepts of development, we can find that today there is a systematic definition of the concept. To achieve these goals, there is a coordination between components. Unlike biological systems in which the structure determines the functions, in a developmental system we do not need to accept a structure conclusively, rather the structure of a system can be adjusted in such a way that the system is in accordance with the developmental process. We can claim that the process is more determinative than the structure in the analysis of the system goals, system resources, system details, and strategic planning.

Two sets of external and internal factors are involved in a developmental system. Wealth distribution, organizations, and motivations are the internal factors, which are related to the external ones, such as international, national, urban, and rural factors. Internal factors have mutual relation with each other, too [10].

Based on what has been mentioned, we can say that development is a phenomenon with differing dimensions, each presented in the human life. Generally, all these dimensions have contributed to the improvement process of the human life; however, each aspect of development is important by itself, thus requires a separate analysis.

\section{The Influence of Tourism in Conservation of Architectural elements:}

Tourism could be regarded as the balanced distribution of economic profits of industrial population centers in target tourism regions. Accumulation of the income from industrial activities in developed regions can be an appropriate source of income for regions that supply tourists' required services and make them have recreational, resting, and refreshing time during their stay. The host society make investments in order to pay for supplying facilities and infrastructures, while expecting return of 
the capital in addition to an acceptable interest. Such an expectation in case of more attractions and more convenient services will be fulfilled in shorter time and with higher interest. In regions like Zonouz and the surrounding population centers natural talents and architectural works provide the opportunity for tourists to benefit from their leisure time more. The opportunity of urban actors' programming to achieve city development goals from tourism income brings about some [9] sustainable income as well as the necessary certainty to support and run short-term and long-term programs and thanks to the social welfare from its income, guarantees people participation to a large extent; even though, sometimes conflicts can be observed between the host society and the tourists. As a result, cultural assiduity training for establishment of behavioral balance in the host society can dismiss the mentioned conflicts.

Sustainable income on the first step can deal with issues such as hard and soft infrastructures, meanwhile architectural attractions, capable of increasing tourist attractions, willy-nilly receive urban managers' attention. On one hand, such riches will increase the tourist's interest in those places and, on the other hand, make him pay extra than his journey in order to arrive at that place.

On the other hand, citizens will have necessary sensitivities to maintain geographical possessions and will understand direct impacts of their own national wealth, since business improvement, just distribution of job opportunities, and value added of their investments will realize under its influence.

Thanks to persistent activities of different public and private sectors, the government will be specifically attentive of these regions, facilitating necessary credit facilities through banks and on the other hand, it will incorporate necessary systems and regulations in its design and programs. It will also implement the infrastructures, able to be implemented only by the government, like communicational axes or connection infrastructures.

These three sectors of actors are the ones that believe historical works belong to them and they are responsible to maintain them [20]. When both the circumstances of paying attention to those works and financial capability becomes possible, all three of them will be interested in playing the role of repairing, maintaining, and operating historical buildings and profiting from them. The result will be renovation of some works which had been forgotten once and were going to be destroyed or damaged.

Now, if we take a brief look at tourism potentials of the cities of Varzaqan in the east, Jolfa in the north, and Marand in the south of Zonouz, we will understand that items like its tourist attractions of Sultan Sanjar with Varzaqan, ruined mill and Kurdash bath with Jolfa, and Sanboran attractions and Laleh plains with Marand are currently administered collectively and such cooperation is due to national divisions and none of the towns are able to manage them as well as other shared attractions alone. On one hand, due to their close proximity to Zonouz, being located around Zonouz's geographical area, these towns can expect shared interests with Zonouz from this plan. On the other hand, the attractions, in accordance to single management can be used by tourists entering Zonouz, hence developing the plan's area, in which case the resultant interests as well as the rate of tourist attraction will increase and, simultaneously, the infrastructures for all four towns will be provided, too. This is the very historical reality of the region, too, that the towns around Zonouz had always interacted with one another and had the expectation of synergy in presenting services to tourism as well as benefits for the cities in case of convergence. The group and its surroundings are a dynamic field, the sustainability of which is determined by social factors, like high pressure, barriers' resistance, and the pursuit of certain goals [8].

\section{Convergence of the Surrounding \\ Towns of Zonouz}

Ernst Haas believes that convergence is a process in which the political representatives of separate units are encouraged to change their loyalty and expectations to a new center. During this process, units move from the relative or total isolation towards the relative or absolute alliance, with their interactions having different dimensions. To determine the center, some notes have the determinant importance. Geographical location of the center is the most important factor, so that all convergent units can be connected to the center. With this analysis, we can say that neighborhood-based selective areas are essential, making it possible overlap different tasks. On the other hand, through convergence, the units can benefit from the management alignment and create larger geographical areas in favor of physical and economic development. In this particular case, geography should be potential for common programming and all units should be located in one province to provide easier access.

In the case study, three counties of East Azerbaijan Province can form convergent units: Marand County with five, DJolfa County with three (Fig. 6), and Varzaghan with two subset towns. These cities have the necessary conditions to become a unified set. The area is limited in the north to Azerbaijan country, in the east to the cities of Aahar and Kaleybar, in the South to Tabriz and Shabestar, and in the West to the city of Khoy.

Considering all tourism potentials, cultural heritage of the Zonouz, and insignificant potentials of Varzaghan in the East, DJolfa in the North, Marand in the West, and South of Zonouz, these cities are able to 
promote tourism industry and use the tourism potentials of Zunouz. Therefore, development of

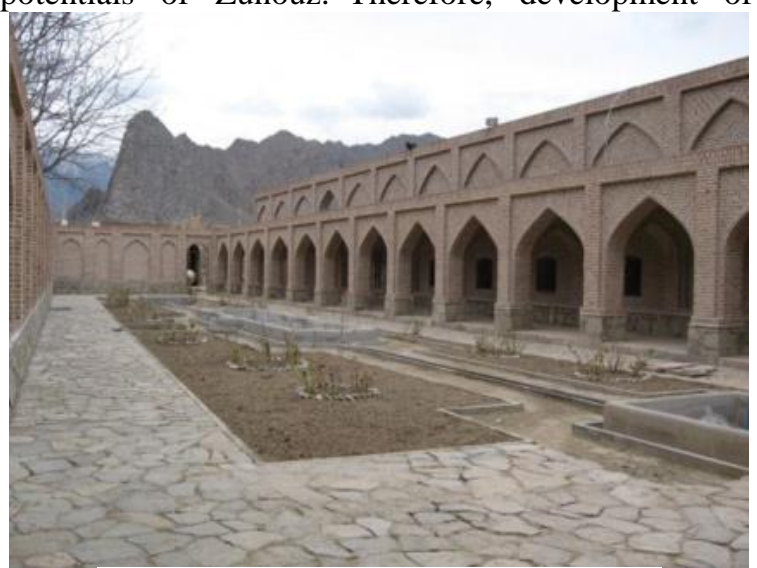

Fig. 6. Bathroom of Djolfa. Photo by the author.

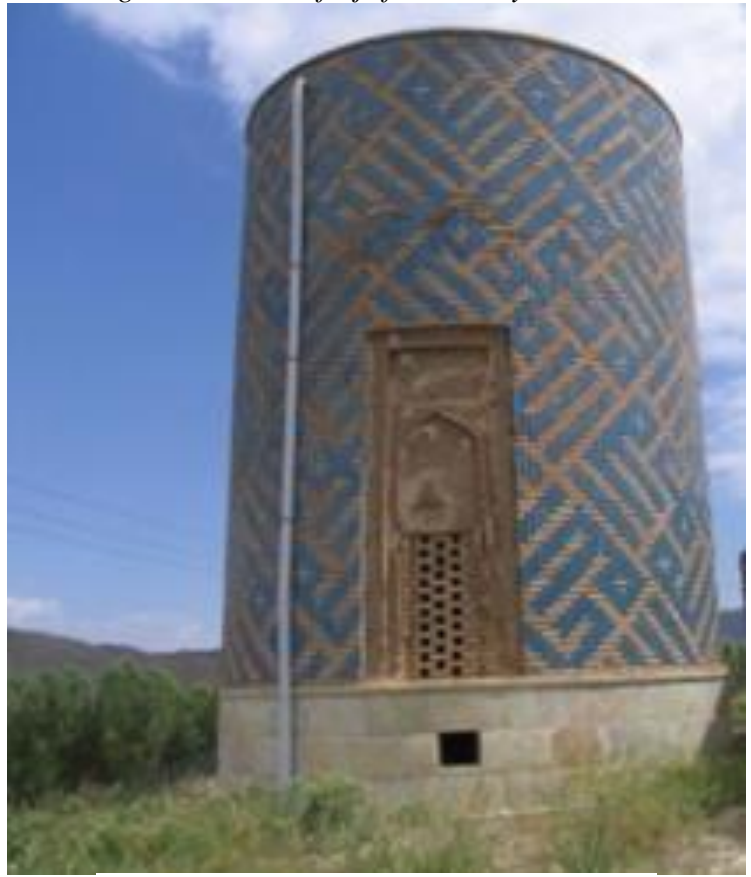

Fig. 7. Allah Allah cupola. Photo by the authors.

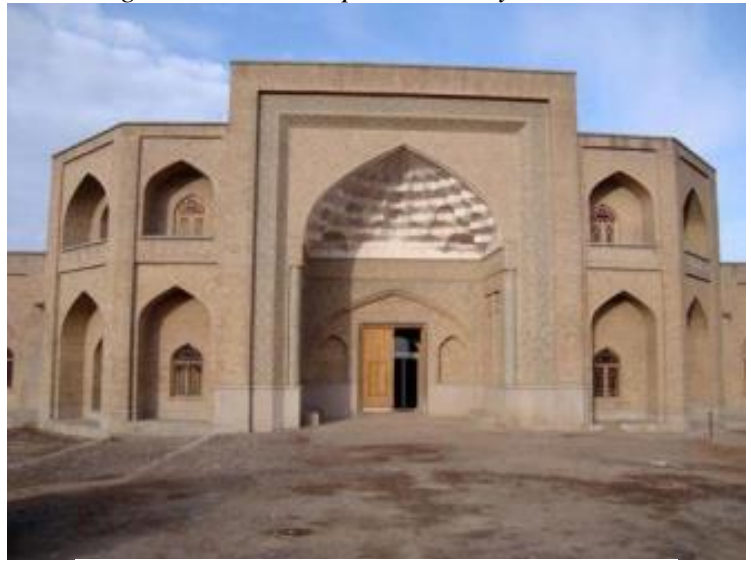

Fig. 8. Marand Caravansary. Photo by the authors.

planning and preservation of the cultural heritage offers specific privileges to any authority and citizen in these cities. Some of these privileges include development of the infrastructures and making communication and transport routes between the cities [18], increases the cities' abilities to stabilize tourism industry.

These cities are located from 30 to $45 \mathrm{Km}$ off Zonouz. Varzaghan has nine tourist attractions, (Fig. 7), DJolfa has six, and Marand has nine tourist attractions (Fig. 8). An integrated management plan for 44 tourist attractions, including natural and historical landmarks of these cities will result in synergy, boosting their economic growth, causing proper protection of the environmental area consequently. It can also assist economic empowerment in different forms, attracting special attention to the historical context of these cities.

\section{Conclusion}

Cultural heritage is a vast and complicated concept. According to the definition, presented by United Nations Cultural Organization (UNESCO), it is "a set of symbolic or artistic shows, inherited to people from their past culture" [1]. As a matter of fact, heritage includes monuments, ancient buildings, landscapes, and customs. For some people, it poses a positive image of the past [12], causing a group of people take pride in their past culture; however, in tourism's point of view, heritage can create cultural development. What is of high account in cultural development and tourism, is the fact that not only does it depend on the correlation between people and things or monuments, but it also relies on intercultural supersensible and spiritual relations, such as behaviors and lifestyle, human relations, and cultures. Travels and connections among people with different cultures play a very valuable role in development of different nations' cultures [13]. If tourism industry pays any attention to the culture, it can help develop cultures, making societies aware of their local and native values. Indeed, cultural tourism creates opportunities for people from different cultures to communicate with one another and find the richness, present in other cultures. Currently, with globalization being taken so seriously, the native and cultural subjects should be protected and introduced. Generally, it can be said that mutual relations between values of cultural heritage and tourism industry are changing and developing. Based on inherent contradictions, this relation brings about either opportunities or threats.

Cultural tourism plans and projects in the heritage field should create opportunities; however, the set of actions that can be done in order to meet visitors' requirements should have minimum negative effects on the host communities along with their heritage [2]. This requires total awareness of the potentials and values of both monuments and cultural heritage.

Feilden \& Jokilehto pointed out the principles of cultural tourism as well as the mutual relations between the values cultural heritage and tourism industry; however, there has not yet been a direct 
research on the relation among cultural heritage values as the most important components to boost tourism industry, its development with regards to the available potentialities and abilities in this area, and architectural and urban heritage as a tourism center.

Our study showed that it is necessary to pay attention to the following issues: (1) The necessity of preserving cultural and historical heritage for sustainable tourism; (2) Cultural activities to introduce cultural heritage in order to attract tourists; (3) Historical landmarks of famous cities are being reconstructed with regards to the economy so that it is culturally sustainable and strengthened by the "idea of sustainable development" of resources, built on human thoughts, talents, and competence. In fact, for historical cities we should consider economic revitalization of the city, based on its cultural sustainability. The income from tourism industry can support the conservational charges of historical buildings and city textures constitute the heart of Zonouz tourism, which allows the managers of these cities to improve tourism-based goals of the cities, so that they can be prepared to plan the conservation of architectural monuments and cultural heritage.

Since all aspects of tourist attractions play a direct role in achieving this goal, they can benefit from its economic distribution as well. We can consider an executive approach by synergy, distributing the convergence benefits among the cities, around their tourism centers to protect the civil context along with other tourist attractions.

\section{References}

1. Afkhami, B. An Introduction to the Relation between Archeology and Cultural Tourism, the research Institute of tourism and cultural heritage. Tehran: Iranian Cultural Heritage and Tourism Organization, 2008. [in Persian]

2. Feilden, M. B., Jokilehto, J. Management Guidelines for World Cultural Heritage Sites. Tehran: University of Tehran Press, 2007, p. 141.

3. Ghafari, S. R., Torki H., Masoumeh, M. The Role of Tourism in Economic and Social Development of Rural Regions. Village and Development Quarterly, 2009, p. 86. [in Persian]

4. International Tourism: A Global Perspective. Gee, C. Y.(ed.). Tehran: Cultural research office publication, 2003, p. 121.

5. Hayami, Y. Development Economics: From the Poverty to the Wealth of Nations. Oxford: Clarendon Press; Oxford; New York: Oxford University Press, 1997, p. 388.

6. Kazemi, S. A Pattern for Determining Economic and Social Situation of Individuals and Evaluation of the Social Movement. Journal of Social Science Letter, 1999, Vol. 14(14) [available at:] https://jnoe.ut.ac.ir/volume_1457.html

7. Kreag, G. The Impacts of Tourism [online]. University of Minnesota, Publication No T 13, 2001 [cited 10.08.2018] http://www.seagrant.umn.edu/tourism/pdfs/ImpactsTourism.pdf

8. Lombardo F. Lewinian Contribution to the Study of Personality as an Alternative to the Mainstream of Personality Psychology in $20^{\text {th }}$ Century. Bydgoszcz: Kazimierz Wielki University Press; 2006, p. 86-98.

9. Moazeni K. Criterion and indexing of Sustainable city tourism [online]. Educational and Research Journal, Vol. 78. Organization of İranian Municipalities, 2007. [cited 10.08.2018] http://www.magiran.com/magtoc.asp?mgID=1108\&Number=78\&Appendix=0 [in Persian]

10. Papeli Yazdi, M. H., Ebrahimi, M. E. Rural Development Theories. Teheran: SAMT Press, 2007, p. 214. [in Persian]

11. Parasmoon Co. Plan of the Physical Development of Urban Tourism and its Surrounding Area. Tehran: Parasmoon 2004-2012, Vol. 2, p. 66.

12. Renfrew, C. Bahn, P. The Fundamental Concept in Archeology. Tehran: Samira Publication, 2011.

13. Rezvani, A. Geography and Tourism Industry. Tehran: Payam Nour Publication, 1995, p. 68

14. Riyazi, J. Trououth Zonouz city of science and culture. qom, Marashi publication, 2005, p. 31. [in Persian]

15. Samadian, A., Hoseini, S. H., Negineh R. A. The Role of Education in the Development of Infrastructure in Tourism Industry. Human Geography Research Quarterly. Tehran: University of Teheran, 2009, Vol. 4, p. 110

16. Shahidi, E. History and culture of Zonouz. Tehran: Hoor press, 2018, p. 73. [in Persian]

17. Shokouyi, H. Didghah haye nov dar gographiyaye Shahri. Tehran: SAMT Press, 1995, p. 98.

18. Walter, M. The Logic of Regional Integration: Europe and Beyond. Cambridge: Cambridge University Press, 1999, p. 214.

19. Zangiabadi, A. Analysis of Tourism Facilities of Kurdistan from Tourists' Point of View. Human Geography Research Quarterly. Tehran: University of Teheran, 2010, $2^{\text {nd }}$ year, Vol. 4, p. 39.

20. Zayari, K. A., Omranzadeh, B. Development of Persian Gulf Tourism with Emphasis on Modern Structures. The $5^{\text {th }}$ Persian Gulf National Conference, 2001.

\section{INFORMATION ABOUT THE AUTHORS:}

Hassan Khalili Zonouz - PhD in Architecture, researcher in historical buildings conservation theories at the Architecture Institute, Azerbaijan National Academy of Sciences; AZ1073, 115, H. Javid ave., Baku, Azerbaijan; e-mail: hassan.khalili@ parasmoon.com

Rahiba Aliyeva - PhD in architecture, Head of the preservation and restoration of Monuments Department, professor at the Architecture Institute, Azerbaijan National Academy of Sciences; AZ1073, 115, H. Javid ave., Baku, Azerbaijan; e-mail: rahibe_eliyeva@mail.ru

Mitra Azad - PhD in Art studies, assistant professor in History of Architecture and Heritage Department at the Faculty of Architecture and Urban Planning, Shahid Beheshti University; Shahid Shahriary square, Evin, Tehran; E-mail: m_azad@sbu.ac.ir 
Kopsavilkums. Zonuzas pilsēta un tās kaimiņu apgabali atrodas dienvidos no Arazas upes Azerbaidžānā, ziemeḷrietumos no Irānas. Zonuzas pilsētai piemīt daudzas potenciālās iespējas, ņemot vērā ǵeogrāfisko lokāciju, civilizāciju un tūrismu, kas var tikt uzskatīti par urbāno attīstību veicinošiem faktoriem.

Pētījuma mērḳis ir izpētīt un salīdzināt tās pilsētas, kuras ir centralizētas, ar relatīvi plašākām iespējām, kā perifērās pilsētas, ar tām pilsētām, kurām ir līdzīgas geogrāfiskās un kulturālās iezīmes, integrēta un papildināta tūrisma nozare.

Lai sasniegtu uzstādīto mērķi, rakstā tiek pētītas un analizētas tūrisma iespējas un objekti, izdarot secinājumus no apkoptās informācijas. Secinājumi par ġeogrāfisko vidi un kultūras mantojumu tiek izmantoti, lai veiksmīgāk aizsargātu un attīstītu vēsturisko dabas un kultūras mantojumu, rodot kopīgu attīstības balansu ar kaiminu pilsētām. 